\title{
Notes
}

\section{Sociology And Rhetoric: Some Personal Musings}

\author{
Michael A. Overington \\ Saint Mary's University
}

Some thirty years ago I found myself starting graduate work in the Department of Sociology at The University of Wisconsin in Madison. This turned out not to have been a good choice. Despite being 31 years old, I was innocent of just how limited had been my exposure to mainstream sociology in my undergraduate years. I had thought that Marx, Weber, and Durkheim were the theorists who had set the ground rules for empirical inquiry, that people lived in groups according to the social meanings they created, that research would involve inquiry in such social groups and their cultural understandings. I was wrong: not at Madison. There, theory had to do with networks of logically connected syllogistic statements that had conclusions with observable consequences; people were individuals whose group life could be reconstructed from their responses to the questions of social surveys; the only valid information about social life had to be collected from randomly sampled individuals. And my task as a graduate student was to be trained into this mainstream.

I took all the courses, wrote all the examinations, completed an MA and Ph.D., and still failed to be trained. And a major part of that failure was my discovery that rhetoric could save me. I had wanted to write my dissertation on Hugh Duncan, Kenneth Burke's greatest disciple, and felt it important to understand Burke and his place in rhetoric. Off I went to the Department of Communication Arts and, without knowing of their eminence, picked up on Ed Black and Lloyd Bitzer as my teachers. All this happened the year that the papers from the path-breaking $1970 \mathrm{Wing}$ spread Conference were published as The Prospect of Rhetoric (Bitzer and Black, 1971). As these men taught it, rhetoric could save me from the narrow strictures of a poorly understood logical positivism that bound the ideology of my own department of sociology. The only problem that I had was that neither Bitzer nor Black could see this route to freedom that I wanted to follow! 
I was convinced that science could be treated as rhetoric; they were unpersuaded. I thought that a rhetorical approach to science offered a promise of cutting the bonds that logical positivism had wrapped around science, opening scientific practise to new forms of inquiry that could include issues of moral responsibility within their protocols. Without the logical maledictions that a positivistic view had placed upon scientific statements, there was a renewed freedom to consider the kinds of worlds that persuasive discourse might create for a variety of scientific audiences. After all, once "meaning" ceases to be the ineluctable outcome of logical reasoning where facts are "given" (the smuggled meaning of data), then surely rhetoricians would grasp scientific meaning as accomplished through a process of social interaction. Therein, persuasive argument would present capta ("matters chosen," if you will) for the moral and epistemological scrutiny of scientific publics.

In my doctoral oral exam I defended a number of theses about the construction of social theory. One of these read something as follows: "The correct form of social theory is the rhyming couplet." I had learned much from my teachers of rhetoric, not merely something of the history of the discipline, but also the ability to proffer a stylish, ironic challenge to the ideology of my department. Neither Bitzer nor Black were greatly impressed with this: persistently innocent, I had little understanding of the nature of disciplinary boundaries over which I was stepping. Indeed, without the principled support of my dissertation supervisor, Joe Elder, I would have failed this exam on the grounds that I was "untrained" and couldn't be certified as a "real" Wisconsin Ph.D.

I had my one "big" idea at Wisconsin. It would be easy enough to say that this idea was that science was rhetorical. But that's not quite it. More exactly, I came to understand what it meant to say that human communication always involved people, their messages, their publics and their contexts, all human communication. I could follow my sociological heart and ask of any human construction of knowledge the same questions without worrying that some practices of knowledge creation had the privilege of not responding to these questions. Anything I have since been able to produce relevant to the rhetoric of science flows directly from that insight. The organizers of Wingspread wrought in me more than they had envisaged. A person marginal to the discipline of rhetoric, breezed through their world at a catalytic moment for the field, and took away more than he or they had known.

I gave papers at conferences in 1974 and 1975; I published collaborative work done in those years (Zollschan \& Overington, 1976); I smuggled part of my thinking (Overington, 1977a) into a response to Joe Gusfield's great pioneering article (1976); finally, in a journal obscure for sociologists, I published the one essay (Overington, 1977b) that people now cite as early, formative, foundational, ... in the contemporary 
rhetoric of science. However, the burden of this essay cannot be fully understood without reading some of my somewhat later essays, particularly $(1979,1981,1982)$, and these are rarely, if ever cited. And the problem is somewhat more interesting than this.

I had wanted to use rhetoric in science as a route to escape from the clutches of sociological positivism and the dead hand it had laid upon invention and inquiry. I had wanted to use rhetoric in the social sciences as a lever to pry loose the vitiating effects that a poorly understood positivism had upon sociology. I wanted to help free my discipline from the claims of most of my teachers and peers that anything other than the "mindless empiricism" of influential, mainstream sociology was some kind of poetic journalism. I had no interest in being part of any movement that would turn into a "rhetoric of science."

I wanted to use rhetoric in science to help me open up a space in which to do my kind of sociology and have it receive a respectful public. Thirty years ago as now, sociology was my interest and any of my writing about rhetoric or philosophy of science was a device, a manoeuvre, a tactic, for exhibiting the vacuity of most sociologists' talk about sociology. That space has opened. When sociologists now talk about their work it is much more connected to their actual practises and not to some poorly understood philosophical gloss of those practises. The diversity of inquiry in sociology is as broad as is our inventional capacities. However, I can see little evidence that any of my published work had much effect on such changes.

When my earlier papers are cited and reprinted in work addressed to sociological publics, it is almost always as part of the decent scholarly code that cites early work. I cannot find evidence that my early papers actually effected these changes in my field. In the sociology of science, my early papers are only cited some ten to fifteen years after their publication. Apparently, the "rhetorical turn" in the social studies of science occurred quite innocent of my earlier work. However, there is now some kind of sense that because I was there early, I was influential; and my early essays are often cited as if this were the case; it is nothing more than an example of post hoc, ergo propter hoc. Yet, among rhetoricians of science who locate themselves in rhetoric as a discipline, my early work continues to be addressed. Gaonkar (1997), for example, actually spends time discussing my essay (1977), dismissing it as a trivial exercise of translating science into rhetoric.

He's correct now. It wasn't quite so trivial twenty-odd years ago, for the point of translating the meanings of one realm into those drawn from another was always for me part of an inventional practice, but in sociology not rhetoric. The point of my exercise in examining sociological inquiries and discourse through a rhetorical lens was to find out what more one could see from such a scrutiny than within the ac- 
cepted gaze of an insider culture. One must always recall that this and other early attempts to see science as rhetorical were undertaken at a time when versions of logical positivism still dominated most talk among scientists about the form and content of scientific discourse.

Examined through rhetoric, my discipline in the social sciences becomes a moral enterprise wherein we sociologists elect the conceptual frameworks within which we ask our questions and later seek to persuade our peers that we have suitable answers. It is no longer sufficient to speak of valid and reliable information as the license for our knowledge claims; sociologists also have to consider their responsibility for a choice of conceptual framework, for the forms of argument that they choose to create plausible conclusions and for the publics that they choose to address.

So, the sum and substance of my involvement with the rhetorical arts has been to reach a place where I can ask of my disciplinary peers: "Why do you do sociology?" "Why do you do that particular kind of sociology?" "For what and to whom will you be responsible for your claims to know about the social world?" If scholars in the rhetoric of science help me pose those questions, then I am still interested in their work; it is, however, not my work and never was.

\section{References}

Bitzer, L. and Black, E. (Eds). (1971). The prospect of rhetoric. Englewood Cliffs, New Jersey: Prentice-Hall.

Gaonkar, D.P. (1997). The idea of rhetoric in the rhetoric of science. In A. Gross and W. Keith (Eds.) Rhetorical hermeneutics (25-85). Albany: SUNY Press.

Gusfield, J. (1976). The literary rhetoric of science: comedy and pathos in drinking driver research. American sociological review, 41, 16-34.

Overington, M. (1977a). A critical celebration of Gusfield's "The literary rhetoric of science." American sociological review, 42, 170-3.

Overington, M. (1977b). The scientific community as audience: toward a rhetorical analysis of science. Philosophy and rhetoric, 10, 143-64.

Overington, M. (1979). Doing the what comes rationally: some developments in metatheory. The american sociologist, 14, 2-12.

Overington, M. (1981). A rhetorical appreciation of a sociological classic: Durkheim's Suicide. The Canadian journal of sociology, 6, 447-61. 
Overington, M. (1982). Responsibility and sociological discourse. Qualitative sociology, 5, 106-20.

Zollschan, G. and Overington, M. (1976). Reasons for conduct and the conduct of reason. In G. Zollschan and W. Hirsch (Eds.) Social change: explorations, diagnoses, and conjectures. New York: John Wiley. 